\title{
Review
}

\section{Intracellular Hyperthermia Using Magnetic Nanoparticles : A Novel Method for Hyperthermia Clinical Applications}

\author{
AKIRA ITO ${ }^{1}$, TAKESHI KOBAYASHI ${ }^{2 *}$ \\ ${ }^{1}$ Department of Chemical Engineering, Faculty of Engineering, Kyushu University, 744 Motooka, Nishi-ku, \\ Fukuoka 819-0395, Japan \\ ${ }^{2}$ School of Bioscience and Biotechnology, Chubu University, Matsumoto-cho 1200, Kasugai, Aichi 487-8501, Japan
}

\begin{abstract}
Magnetic nanoparticle-mediated intracellular hyperthermia has been a largely experimental modality of hyperthermia, but this treatment modality has the potential to achieve tumor targeted heating without any side effects. The technique consists of targeting magnetic nanoparticles to tumor tissue and then applying an external alternating magnetic field to induce heat generation by the magnetic nanoparticles. Among available magnetic nanoparticles, magnetite has been extensively studied. Recent years have seen remarkable advances in magnetite nanoparticle-mediated hyperthermia; both functional magnetite nanoparticles and alternating magnetic field generators have been developed. Currently, some researchers are attempting to begin clinical trials, suggesting that time may have come for clinical applications. This review describes recent advances in magnetite nanoparticle-mediated hyperthermia.
\end{abstract}

Key Words : intracellular hyperthermia, magnetite nanoparticles, drug delivery system, magnetic field

Introduction

"Quae medicamenta non sanat; ferrum sanat. Quae ferrum non sanat; ignis sanat. Quae vero ignis non sanat; insanabilia reportari oportet. Hippocrates." This quote from Hippocrates can be translated as: Those diseases which medicines do not cure, the knife cures; those which the knife cannot cure, fire cures; and those which fire cannot cure, are to be reckoned wholly incurable.

From this aphorism by Hippocrates (460-370 BC), it appears that he may have believed that diseases could be cured by heating a patient's body. Today, the rationale for using hyperthermia in cancer therapy is well established; sustained temperatures above $42^{\circ} \mathrm{C}$ will cause necrosis and/or apoptosis of cancer cells $\mathrm{s}^{1-4)}$. Thus, hyperthermia is a promising approach to cancer therapy, in part, because hyperthermia is a physical treatment and could result in fewer side effects than chemotherapy or radiotherapy. This could permit the use of repeated hyperthermia treatments.

A major technical problem with the currently available hyperthermia modalities, including whole

Received 6 October, 2008, Accepted 2 December, 2008. ${ }^{*}$ Corresponding author, Tel, +81-568-51-6342; Fax, +81-568-52-6594;

e-mail,kobatake@isc.chubu.ac.jp

doi : $10.3191 /$ thermalmed.24.113

(C) 2008 Japanese Society for Thermal Medicine 
body hyperthermia ${ }^{5)}$ and radiofrequency capacitance hyperthermia ${ }^{6-8)}$, is the difficulty of heating a local tumor region to the desired temperature without damaging normal tissue. High temperatures above $42.5^{\circ} \mathrm{C}$ can kill a great number of tumor cells, but normal tissues are also severely damaged under these conventional hyperthermia treatments. Therefore, the development of novel hyperthermia systems which can heat tissue to around $42.5^{\circ} \mathrm{C}$ and which are capable of specifically targeting tumor cells and tissue is required.

Magnetic nanoparticle-mediated hyperthermia is a largely experimental modality for hyperthermia application which has the potential to overcome these shortcomings ${ }^{9,10)}$. This technique consists of targeting magnetic nanoparticles to tumor tissue, and then applying an external alternating magnetic field to induce heat generation in the nanoparticles via hysteresis loss and relaxational loss. Recent years have seen remarkable advances in magnetic nanoparticle-mediated hyperthermia; both tumor-targeted magnetic nanoparticles and alternating magnetic field generators have been developed, and some of these are just entering into clinical trials ${ }^{11-14)}$. This review covers recent advances in magnetic nanoparticle-mediated hyperthermia and discusses future directions.

\section{Magnetic nanoparticles for intracellular hyperthermia}

Various heating methods have been used for hyperthermia applications ${ }^{15)}$. However, an inevitable technical problem with hyperthermia is the difficulty of uniformly heating only the tumor region to the required temperature without damaging surrounding normal tissue. As a result, some researchers have proposed the use of "intracellular" hyperthermia to provide a tumor-specific hyperthermia system, and submicron magnetic particles (typically less than $100 \mathrm{~nm}$ in diameter) have been developed for this purpose.

Any submicron magnetic particles which can generate heat under an alternating magnetic field can theoretically be used for intracellular hyperthermia. However, the most important criterion is that the magnetic particles be non-toxic. Because of this requirement, magnetite $\left(\mathrm{Fe}_{3} \mathrm{O}_{4}\right)$ and maghemite $\left(\gamma-\mathrm{Fe}_{2} \mathrm{O}_{3}\right)$ particles have been the focus of most studies. Maghemite is produced by the oxidation of magnetite above $300^{\circ} \mathrm{C}$, and the steps required to produce magnetite are simpler than those required to produce maghemite. The heating properties of magnetite and maghemite are comparable for use in intracellular hyperthermia. Therefore, most studies of submicron magnetic particles for intracellular hyperthermia have focused on magnetite.

In 1979, Gordon et al first proposed the concept of intracellular hyperthermia ${ }^{16)}$. Six nm diameter magnetite particles suspended in a sucrose solution were injected into a tail vein, and the selective uptake of particles by a tumor was observed with light microscopy and electron microscopy.

In 1993, Jordan et al developed $15 \mathrm{~nm}$ aminosilan-coated magnetite nanoparticles in order to enhance cellular uptake and prevent intracellular digestion of the particles ${ }^{17)}$. As a result, intracellular hyperthermia showed a more potent cell killing effect than heating in a water bath. Thus, the use of coated magnetite nanoparticles provided a promising approach for intracellular hyperthermia.

In Japan, three laboratories are currently developing intracellular hyperthermia systems using magnetite nanoparticles. These groups are Hiraoka et al (Kyoto University) ${ }^{18-21)}$, Tazawa et al (Toyama University) $^{22-24)}$ in collaboration with Nagano et al (Kanazawa University), and Kobayashi et 
al (formerly at Nagoya University, and now at Chubu University) ${ }^{25-61)}$.

When magnetic nanoparticles are used in in vivo studies, the lack of colloidal stability of these magnetic nanoparticles is an important issue. A possible approach to overcome this shortcoming of magnetic colloids is coating the magnetic nanoparticles with dextran. Dextran magnetic particles (commercially available as the magnetic resonance imaging (MRI) contrast agent Resovist ${ }^{\circledR}$ ) was developed by the Meito Sangyo Co. (Nagoya, Japan) ${ }^{62}$. Resovist $^{\circledR}$ is a complex of magnetic nanoparticles (diameter, $50 \mathrm{~nm}$ ) surrounded by dextran, which is chemically bound to its surface, and is stable as a colloid and can be mixed with various solvents or serum without aggregating or precipitating. The literature ${ }^{62)}$ states that the core is maghemite, and Hergt $e t$ al ${ }^{63)}$ agreed that the core of these particles is maghemite judging from analysis using X-ray diffraction. However, Hiraoka et al ${ }^{18-20)}$ and Tazawa et $a l^{22-24)}$ stated that they used magnetite-core dextran nanoparticles donated by Meito Sangyo Co., for which no preparation method has yet been published. Resovist ${ }^{\circledR}$ was first applied clinically for detecting liver cancer, since Resovist ${ }^{\circledR}$ is taken up rapidly by the reticuloendothelial systems, such as the Kupffer cells of the liver, and when compared to uptake by liver cancer cells. Kupffer cells exist in normal liver but are not present in liver cancer. Therefore, Resovist ${ }^{\circledR}$ has the potential to enhance relaxivity in a normal liver under MRI conditions. However, the magnetite-core dextran nanoparticles are ingested by cancer cells according to Tazawa et $a l^{22-24)}$, and Hiraoka et $a l^{18-20)}$ and Tazawa et $a l^{22-24)}$ used magnetite-core dextran nanoparticles as a heating mediator in vivo.

For drug delivery systems (DDS), liposomal coatings provide a promising approach. Shinkai et al (Kobayashi et al) used DDS techniques with liposomes, to provide intracellular hyperthermia ${ }^{28)}$. An accumulation of magnetite nanoparticles (with a diameter of $10 \mathrm{~nm}$ ) in tumor cells can be enhanced by conferring a positive surface charge to the liposomal surface. This group has developed "magnetite cationic liposomes (MCLs)" with improved adsorption and accumulation properties ${ }^{28,33)}$. MCLs, which have a positive surface charge, have a ten-fold higher affinity for glioma cells than neutrally charged magnetoliposomes as shown in Fig. 1.

Furthermore, a significant development in intracellular hyperthermia occurred when Kobayashi et al developed antibody-conjugated polyethylene glycol derivatives containing magnetite ${ }^{27)}$ and antibodyconjugated liposomes containing magnetite nanoparticles (antibody-conjugated magnetoliposomes, AMLs; core diameter, $10 \mathrm{~nm}$ ). They constructed AMLs using mouse G22 monoclonal antibodies (MAb) against human glioma cells ${ }^{26,29)}$, mouse $\mathrm{G} 250 \mathrm{MAb}$ against human renal cell carcinomas ${ }^{36,39)}$ and humanized $\mathrm{MAb}$ against human epidermal growth factor receptor-2 (HER2) $\quad\left(\text { Herceptin }^{\circledR}\right)^{54)}$, MAb against human high

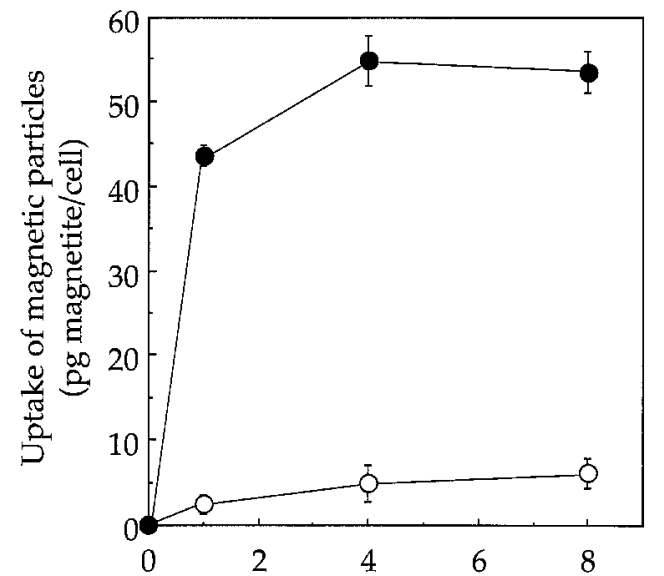

Time after addition of magnetic particles (h)

Fig. 1. Comparison of magnetite uptake between MCL and ML. Open and closed symbols indicate data for magnetoliposomes (MLs) and magnetite cationic liposomes (MCLs), respectively. MCLs were taken up by cancer cells via electrostatic interaction. The maximum MCL uptake $(55 \mathrm{pg} /$ cell $)$ was achieved after $4 \mathrm{~h}$, and was ten times higher than that for MLs. 
molecular weight-melanoma associated antigen (HMW-MAA) (unpublished results), and demonstrated the tumor-specific targeting ability of these AMLs as shown in Fig. 2 for human renal cell carcinomas ${ }^{39)}$.

Recently, Kobayashi et al have also developed oligosaccharide-conjugated liposomes containing magnetite nanoparticles (oligosaccharides-conjugated magnetoliposomes, OMLs) ${ }^{60)}$. In the case of mannotriose-conjugated magnetoliposomes, macrophages specifically recognize OMLs via carbohydrate receptors such as the macrophage-mannose-receptor (CD206), and these can be used as a cellular vehicle for targeting macrophages.

The melanogenesis substrate, $\mathrm{N}$-propionyl-cysteaminylphenol (NPrCAP), is selectively incorporated into melanoma cells and inhibits their growth by production of cytotoxic free radicals ${ }^{64)}$. Based upon the unique biological properties of NPrCAP, Jimbow et al at Sapporo Medical University have established a novel chemo-thermotherapy which was demonstrated in a B16 mouse melanoma system. These workers constructed a particle with a conjugated NPrCAP on the surface of magnetite nanoparticles (NPrCAP/ $\mathrm{M})$ which selectively leads to the disintegration of melanoma cells and generates heat upon exposure to alternating magnetic fields ${ }^{14)}$.

When tumors are located in organs with a high blood flow, the temperature of the tumors heated with magnetic nanoparticles does not increase as much as desired, because heat is dissipated by the blood flow. Needle-type metal implants ${ }^{65,66)}$ have been developed for such situations. The needle-type metal implants can generate heat and increased temperatures in organs with a high blood flow. However, the temperature of tumor tissues located at a distance from the implants does not increase above $42.5^{\circ} \mathrm{C}$. In such cases, regrowth of the tumor can occur from tumor cells which were located at a distance from the implants. Furthermore, the implants must be removed from the body after hyperthermia. Kobayashi et al developed a magnetite needle ${ }^{43,44)}$, in which magnetite nanoparticles are molded with carboxymethyl cellulose into a needle shape. It was possible to adminisister the needle within a few minutes, and the temperature rise was very rapid in organs with a high blood flow due to the very high magnetite concentration. These results suggest that magnetite needles could provide very simple and effective particulate heating mediators.

One of the characteristics of magnetite nanoparticles is the distribution of the particles within tumor tissues after repeated hyperthermia ${ }^{45)}$ as shown in Fig. 3. When MCLs were injected into tumor tissues, they remained at the injected site because of electrostatic interactions between the MCLs and the tumor 


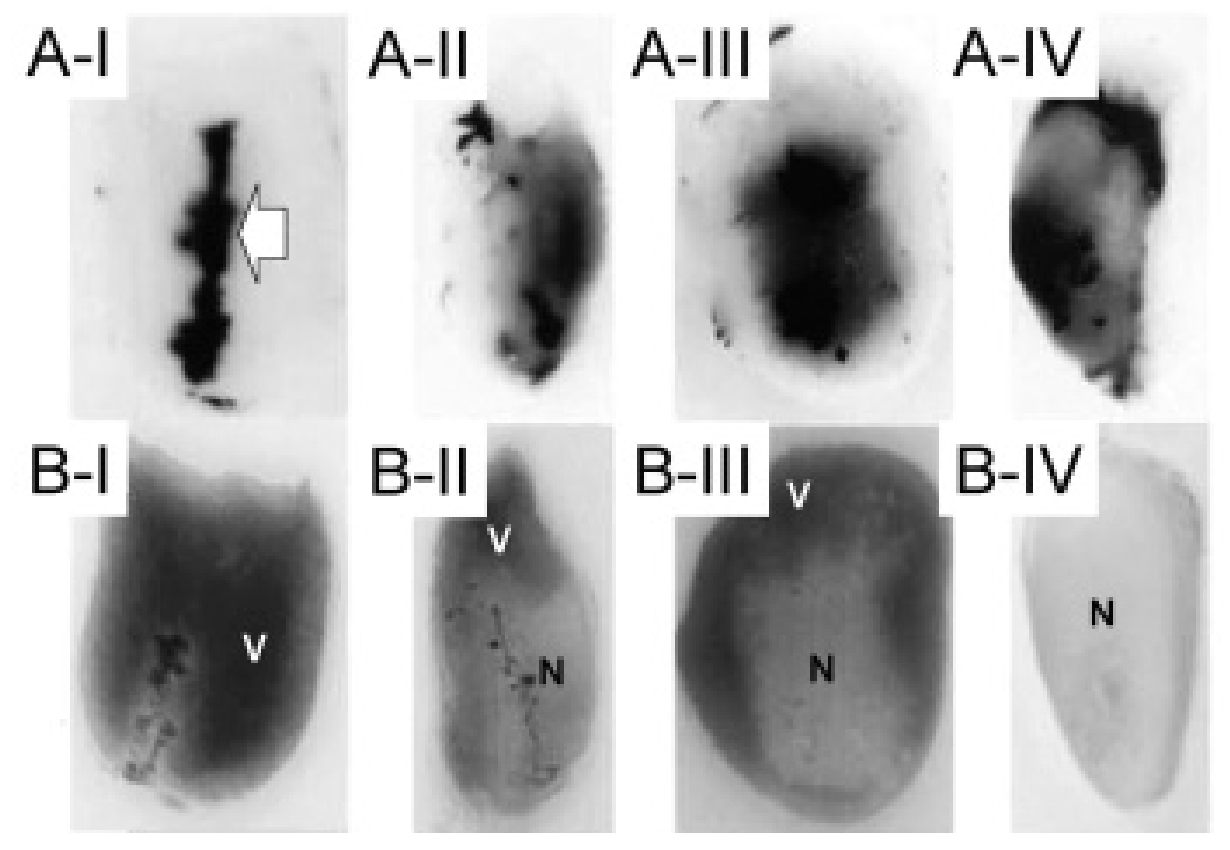

Fig. 3. Photographs of tumor specimens. Tumors were resected at $24 \mathrm{~h}$ after hyperthermia and were (A) paraffinized and (B) histologically stained with hematoxylin-eosin. I : without alternating magnetic field irradiation, II : irradiated once for $30 \mathrm{~min}$, III : irradiated twice for $30 \mathrm{~min}$, IV: irradiated three times for $30 \mathrm{~min}$. An arrow indicates MCLs. $\mathrm{N}$ and $\mathrm{V}$ in the photographs indicate necrotic tissues (pale region) and viable tissues (dark region), respectively.

cell membrane. When the first hyperthermic treatment was applied, the temperature of the MCLs increased above $42.5^{\circ} \mathrm{C}$, and the tumor cells located near the MCLs were killed. In this necrotic area, the MCLs diffused and spread within the tumor. After repeated hyperthermic treatments, additional diffusion occurs, and the MCLs can expand into the entire tumor tissue. In this case, the removal of the particles is not necessary, because the particles are carried away by blood flow after several hyperthermic treatments.

Several types of magnetite nanoparticles are listed in Table I. The magnetite core sizes range from $5 \mathrm{~nm}$ to $15 \mathrm{~nm}$. When used for hyperthermia, the effective absorption of the energy of an alternating magnetic field is an important property of magnetite nanoparticles. Chan et al reported on modified dextran magnetite and its hyperthermic effect using several human carcinoma cell lines in vitro ${ }^{67}$. The specific absorption rate (SAR) (which indicates the heat evolution rate in hyperthermia) of the dextran magnetite particles was low because conventional dextran magnetite with a size of less than $10 \mathrm{~nm}$ behaves as a superparamagnetic particle rather than a ferromagnetic one due to their small size, so that the hysteresis loss was very low. Chan et al controlled the oxygen concentration during the preparation of the dextran magnetite and selected particles of around $15 \mathrm{~nm}^{67)}$. Shinkai et al have reported that particle size is a critical factor in obtaining a high SAR value ${ }^{25}$. In the case of magnetite, the SAR value for $35-\mathrm{nm}$ particles was the highest in the particle size range of $5 \mathrm{~nm}-70 \mathrm{~nm}^{25}$.

In general, magnetic characteristics depend on the particle size and on the methods used for the 
Table I. Magnetite nanoparticles for intracellular hyperthermia

\begin{tabular}{|c|c|c|c|}
\hline Name & Core size & Characters & References \\
\hline Magnetite & $6 \mathrm{~nm}$ & $\begin{array}{l}\text { The first reported for intracellular } \\
\text { hyperthermia }\end{array}$ & {$[16]$} \\
\hline $\begin{array}{l}\text { Aminosilane-coated } \\
\text { magnetite }\end{array}$ & $15 \mathrm{~nm}$ & $\begin{array}{l}\text { Enhances the uptake by cancer cells, } \\
\text { prevents intracellular digestion }\end{array}$ & {$[17]$} \\
\hline Dextran magnetite & $5-10 \mathrm{~nm}$ & $\begin{array}{l}\text { Enhances the blood circulation time, } \\
\text { stabilizes the colloidal solution }\end{array}$ & {$[18]$} \\
\hline $\begin{array}{l}\text { Magnetite cationic } \\
\text { liposome (MCL) }\end{array}$ & $10 \mathrm{~nm}$ & $\begin{array}{l}\text { Enhances the uptake by cancer cells, } \\
\text { stabilizes the colloidal solution }\end{array}$ & {$[28]$} \\
\hline $\begin{array}{l}\text { Antibody-conjugated } \\
\text { magnetoliposome (AML) }\end{array}$ & $10 \mathrm{~nm}$ & $\begin{array}{l}\text { Targets to tumor cells, stabilizes } \\
\text { the colloidal solution }\end{array}$ & {$[26][39][54]$} \\
\hline $\begin{array}{l}\text { Oligosaccharides-conjugated } \\
\text { magnetoliposome (OML) }\end{array}$ & $10 \mathrm{~nm}$ & Targets to macrophages & {$[60]$} \\
\hline $\begin{array}{l}\text { NPrCAP-conjugated magnetite } \\
\text { nanoparticle (NPrCAP/M) }\end{array}$ & $10 \mathrm{~nm}$ & $\begin{array}{l}\text { Targets to melanoma cells, } \\
\text { exerts chemotherapeutic effects }\end{array}$ & {$[14]$} \\
\hline
\end{tabular}

preparation of submicron magnetic particles. Multi-domain ferromagnetic characteristics change to single-domain ferromagnetic, and finally, to superparamagnetic characteristics as the particle size decreases ${ }^{68)}$. Multi-domain ferromagnetic particles possess lower hysteresis losses than single-domain ferromagnetic particles. Therefore, single-domain ferromagnetic particles generate more heat when exposed to an alternating magnetic field as shown by Shinkai et $a l^{25)}$ and Hergt et $a l^{63)}$. Superparamagnetic particles have no hysteresis losses, and generate heat due to relaxational losses in an alternating magnetic field as mentioned by Hergt $e t a l^{63}$. Therefore, two types of loss mechanisms have been found to be of interest for hyperthermia : hysteresis losses and relaxational losses ${ }^{63,69)}$. Both loss types show a non-monotonic dependence of loss with particle size : i.e., there exist optimum particle sizes which are different for each loss mechanism. Hysteresis losses increase with decreasing particle size due to increasing remanence and coercivity until the Néel relaxation effects appear. There, in a narrow transition region to superparamagnetic behavior, remanence and coercivity decrease abruptly ${ }^{63,699}$.

Okawa et $a l^{70)}$ synthesized four kinds of magnetite particles having average sizes of 7, 18, 40, and $80 \mathrm{~nm}$, and investigated their heating ability when they were dispersed in an agar gel and exposed to an alternating magnetic field at $120 \mathrm{kHz}$. The particles which had an average diameter of $18 \mathrm{~nm}$ possessed the highest heating ability, although they exhibited narrow hysteresis loops when compared to particles having average diameters of 40 and $80 \mathrm{~nm}$. This indicated that hysteresis loss did not contribute much to the heat rise generated by the $120 \mathrm{kHz}$ alternating field, and the Neel relaxation loss contributed predominantly to the heat rise caused by the $18 \mathrm{~nm}$ sized particles.

Magnetic materials suitable for hyperthermia are also discussed by Atsumi et al in terms of their magnetic properties, practical limitations in treatment conditions, and of instrumentation ${ }^{71}$. The 
experimental results suggested that either ferromagnetic particles with a very low anisotropy constant, or superparamagnetic particles with a moderate anisotropy constant are suitable. Considering the magnetic- and biocompatibility of the particles, superparamagnetic $\mathrm{Fe}_{3} \mathrm{O}_{4}$ with a diameter of $11-13 \mathrm{~nm}$ was considered the most promising by this group.

\section{Magnetic field applicators for intracellular hyperthermia}

During the past decade or so, various magnetic particles possessing biocompatiblilty, injectability, and high-levels of accumulation in the target tumor have been developed for intracellular hyperthermia. After the particles have been selectively taken up by tumor cells, an external alternating magnetic field is applied to tumor tissues. However, even if an alternating magnetic field generator is not available, the temperature of the tumor tissues is preferentially elevated when radiofrequency capacitive heating is applied as reported by Kobayashi et $a l^{35,41,42)}$. Radiofrequency capacitive heating is popular in clinical hospital settings in Japan, and intracellular hyperthermia using radiofrequency capacitive heating is one of the choices available for clinical applications. In this case, magnetite particles in the tumor tissues may attract more electrical current than normal tissues, and the temperature difference between the tumor tissues and the non-tumor tissues can reach 2 to $3^{\circ} \mathrm{C}$. However, the temperature of the non-tumor tissues located between the electrodes inevitably increases in the case of radiofrequency capacitive heating, and a selective heating system for tumor tissues is desirable. Therefore, the development of alternating magnetic field generators is indispensable for precisely targeted intracellular hyperthermia.

Alternating magnetic field generators have been developed by some companies and universities. In Germany, MagForce Nanotechnologies developed the MFH 300F $100 \mathrm{kHz}$ magnetic field applicator for intracellular hyperthermia ${ }^{722}$. The magnetic applicator in the MFH $300 \mathrm{~F}$ instrument is a "gap type" generator with a C-type toroidal core, and patients are placed inside the aperture. The width of the aperture is $70 \mathrm{~cm}$ and the gap size is adjustable from $21 \mathrm{~cm}$ to $45 \mathrm{~cm}$. Using the MFH 300F, Gneveckow et $a l^{72)}$ found a magnetic field intensity of up to $18 \mathrm{kA} / \mathrm{m}$ in a cylindrical treatment area $20 \mathrm{~cm}$ in diameter and an aperture height of up to $30 \mathrm{~cm}$. The SAR can be controlled directly by the magnetic field strength during the treatment. In Japan, Hiraoka et al ${ }^{19)}$ developed an alternating magnetic field generator which is a cooled, gap-type generator with a C-type toroidal core. It generates a $100-\mathrm{kHz}$ alternating magnetic field. They reported that the magnetic field was uniform in the $10 \mathrm{~cm} \times 10 \mathrm{~cm}$ area between the cores, and gap space is $25 \mathrm{~cm}$.

In Japan, some solenoid type magnetic applicators have also been developed. The Yamamoto Vinyter Co. (Osaka, Japan) and Tazawa et al developed the inductive heating system TY-1, which consisted of four rolls of water-cooled hollow coils ${ }^{23)}$. TY-1 generates a $500 \mathrm{kHz}$ alternating magnetic field. Furthermore, Tazawa et al described a "portable" inductive heating system ${ }^{22)}$. The device can use an alternating current (AC) of $200 \mathrm{~V}$ (maximum output $3 \mathrm{~kW}$ ), and it is extremely small $(40 \times 40 \times$ $40 \mathrm{~cm}$ long). In addition, the frequency can be adjusted continuously within the range of $100-500 \mathrm{kHz}$.

In 1996, the Dai-Ichi High Frequency Co. (Tokyo, Japan) and Kobayashi et al developed a solenoid type magnetic applicator ${ }^{28)}$. An alternating magnetic field was generated by a horizontal coil (inner diameter, $7 \mathrm{~cm}$; length, $7 \mathrm{~cm}$ ) driven by a transistor inverter at a frequency of $118 \mathrm{kHz}$. In preclinical studies using rats, the animals were placed inside of the coil so that the region containing the 
subcutaneously transplanted glioma tumor was at the center, and exposure to an alternating magnetic field was found to produce strong therapeutic effects ${ }^{31)}$. However, it is technically difficult to scale up the coil size in this solenoid type applicator for clinical use because the very large coil which would be required to accommodate a human body may be accompanied by serious risks associated with the presence of the high voltage between the two ends of the solenoid. Therefore, a new device was recently developed, called a "Ferrite core-inserted solenoid type"59). A near-lossless MnZn ferrite core, which has a high relative intrinsic permeability, typically 3000 - 4000 at low magnetic field strengths, and a sharp transition from the ferromagnetic to nonmagnetic states was inserted into a vertical coil. An alternating magnetic field was generated by a vertical coil (inner diameter, $7 \mathrm{~cm}$; length, $9 \mathrm{~cm}$ ) driven by a transistor inverter at a frequency of $360 \mathrm{kHz}$. The ferrite core inside a solenoid coil was designed to concentrate the magnetic field generated by solenoid coil, resulting in the emission of the magnetic field from the surface of the device. Using this magnetic applicator, Kawai et al. reported that in the case of a phantom with MCLs, a phantom $10 \mathrm{~mm}$ distant from the ferrite core-inserted solenoid could show an increase in temperature of $8^{\circ} \mathrm{C}$ within $5 \mathrm{~min}^{59)}$, suggesting that the ferrite core-inserted solenoid was suitable for heating a target positioned outside of the coils.

The alternating magnetic field generators cited here are listed in Table II. These magnetic applicators generate alternating magnetic fields with several frequencies ranging from $100 \mathrm{kHz}$ to 500 $\mathrm{kHz}$. Because the heating properties of magnetite nanoparticles are proportional to the frequencies of the magnetic applicator ${ }^{22)}$, higher temperatures can be generated by magnetite nanoparticles by irradiation with a higher frequency. In our experience, however, higher frequencies, such as those over $400 \mathrm{kHz}$, caused non-specific heating due to eddy currents (unpublished results). This phenomenon was observed when a solenoid type applicator was used, suggesting that the appropriate frequency used in solenoid type applicators should be relatively low frequencies ranging from $100 \mathrm{kHz}$ to $200 \mathrm{kHz}$. The heat generated is proportional to the concentration of magnetite nanoparticles, and also proportional to the 1.6 (obtained experimentally ${ }^{25)}$ ) or 2.0 (estimated theoretically ${ }^{63)}$ ) power of the magnetic field intensity. In addition, the particle size and the preparation methods used to make the submicron

Table II. Magnetic field applicators for intracellular hyperthermia

\begin{tabular}{llll}
\hline Manufacturer & Type of applicator & Frequency & References \\
\hline MagForce Nanotechnologies & Gap type & $100 \mathrm{kHz}$ & {$[72]$} \\
Sumitomo Metal Industries & Gap type & $100 \mathrm{kHz}$ & {$[19]$} \\
Yamamoto Vinyter & Solenoid type & $500 \mathrm{kHz}$ & {$[23]$} \\
Komatsu Power Tron & $\begin{array}{l}\text { Solenoid type } \\
\text { (portable) }\end{array}$ & $100-400 \mathrm{kHz}$ & {$[22]$} \\
Dai-ichi High Frequency & $\begin{array}{l}\text { Solenoid type } \\
\text { Ferrite core-inserted } \\
\text { solenoid type }\end{array}$ & $118 \mathrm{kHz}$ & {$[28]$} \\
\hline
\end{tabular}


magnetic particles are strongly associated with their ability to generate heat as mentioned above. Thus, a number of parameters are important, and the relationship of the frequency used, the particle size used, the preparation methods used to make submicron magnetic particles, their concentration, and the type of applicator used must be optimized for an effective therapy involving intracellular hyperthermia.

\section{In vivo experimental results using intracellular hyperthermia}

The first in vivo experiment with intracellular hyperthermia was performed by Gordon et al ${ }^{16)}$ in 1979. Their study was conducted on 26 Sprague Dawley rats bearing mammary tumors. Non-coated magnetite nanoparticles $(100 \mathrm{mg}$ ) with a $6 \mathrm{~nm}$ diameter were injected into a vein. Microscopic tissue analysis revealed that the tumor cells had taken up the particles. Two days after injection, the rats were exposed to a $450 \mathrm{kHz}$ alternating magnetic field for $12 \mathrm{~min}$. Tumor temperatures increased about $8^{\circ} \mathrm{C}$. It was also reported that there were no side effects or toxic reactions to the particles, and histologic evidence for tumor necrosis was shown.

During the past decades from this first in vivo experiment by Gordon et al ${ }^{16)}$, many researchers have reported encouraging results using intracellular hyperthermia with magnetic nanoparticles, such as magnetite-core dextran nanoparticles ${ }^{18-20,22-24)}$ and aminosilane-coated magnetite ${ }^{73,74)}$. One of the most

Table III. In vivo experimental results of intracellular hyperthermia using MCLs

\begin{tabular}{|c|c|c|c|c|}
\hline Animal & Tumor (size) & $\begin{array}{l}\text { Therapy protocol } \\
\text { (repeated hyperthermia, RH) }\end{array}$ & $\begin{array}{l}\text { Complete tumor } \\
\text { regression }\end{array}$ & References \\
\hline \multirow[t]{3}{*}{ Mouse } & $\begin{array}{l}\text { B16 melanoma } \\
(5-6 \mathrm{~mm})\end{array}$ & $\begin{array}{l}\text { Irradiated } 2 \text { times } \\
\text { at } 46^{\circ} \mathrm{C} \text { for } 30 \mathrm{~min}\end{array}$ & $90 \%(9 / 10)$ & {$[47]$} \\
\hline & $\begin{array}{l}\text { MM46 mammary } \\
\text { carcinoma }(7 \mathrm{~mm})\end{array}$ & $\begin{array}{l}\text { Irradiated } 3 \text { times } \\
\text { at } 45^{\circ} \mathrm{C} \text { for } 30 \mathrm{~min}\end{array}$ & $100 \%(5 / 5)$ & {$[50]$} \\
\hline & $\begin{array}{l}\text { MM46 mammary } \\
\text { carcinoma }(15 \mathrm{~mm})\end{array}$ & $\begin{array}{l}\text { Irradiated } 2 \text { times } \\
\text { at } 45^{\circ} \mathrm{C} \text { for } 30 \mathrm{~min}(\mathrm{RH}) \\
\mathrm{RH} \text { was conducted } 1-6 \text { times }\end{array}$ & $100 \%(5 / 5)$ & {$[50]$} \\
\hline \multirow[t]{3}{*}{$\begin{array}{l}\text { Athymic } \\
\text { mouse }\end{array}$} & $\begin{array}{l}\text { PC-3 human } \\
\text { prostate cancer } \\
(7 \mathrm{~mm})\end{array}$ & $\begin{array}{l}\text { Irradiated } 3 \text { times } \\
\text { at } 46^{\circ} \mathrm{C} \text { for } 30 \mathrm{~min}(\mathrm{RH}) \\
\mathrm{RH} \text { was conducted } 1-5 \text { times }\end{array}$ & $100 \%(5 / 5)$ & {$[59]$} \\
\hline & $\begin{array}{l}\text { LNCaP human } \\
\text { prostate cancer } \\
(7 \mathrm{~mm})\end{array}$ & $\begin{array}{l}\text { Irradiated } 3 \text { times } \\
\text { at } 46^{\circ} \mathrm{C} \text { for } 30 \text { min }(\mathrm{RH}) \text {, } \\
\mathrm{RH} \text { was conducted } 2-5 \text { times }\end{array}$ & $100 \%(5 / 5)$ & {$[59]$} \\
\hline & $\begin{array}{l}\text { Human breast } \\
\text { cancer BT474 }\end{array}$ & $\begin{array}{l}\text { Irradiated } 3 \text { times } \\
\text { at } 45^{\circ} \mathrm{C} \text { for } 30 \mathrm{~min}\end{array}$ & $100 \%(5 / 5)$ & {$[61]$} \\
\hline $\begin{array}{l}\text { Transgenic } \\
\text { mouse }\end{array}$ & $\begin{array}{l}\text { Primary skin } \\
\text { Melanoma }(5-7 \mathrm{~mm})\end{array}$ & $\begin{array}{l}\text { Irradiated } 3 \text { times } \\
\text { at } 45^{\circ} \mathrm{C} \text { for } 30 \mathrm{~min}(\mathrm{RH}) \text {, } \\
\mathrm{RH} \text { was conducted } 1-3 \text { times }\end{array}$ & $100 \%(5 / 5)$ & {$[58]$} \\
\hline Rat & T-9 glioma $(13 \mathrm{~mm})$ & $\begin{array}{l}\text { Irradiated } 3 \text { times } \\
\text { at } 43-44^{\circ} \mathrm{C} \text { for } 30 \mathrm{~min}\end{array}$ & $80 \%(4 / 5)$ & {$[31]$} \\
\hline Hamster & $\begin{array}{l}\text { Os515 osteosarcoma } \\
(10 \mathrm{~mm})\end{array}$ & $\begin{array}{l}\text { Irradiated } 3 \text { times } \\
\text { at } 42^{\circ} \mathrm{C} \text { for } 30 \mathrm{~min}\end{array}$ & $100 \%(4 / 4)$ & {$[53]$} \\
\hline Rabbit & $\begin{array}{l}\text { VX-7 squamous cell } \\
\text { carcinoma }(10 \mathrm{~mm})\end{array}$ & $\begin{array}{l}\text { Irradiated } 3 \text { times } \\
\text { at } 43^{\circ} \mathrm{C} \text { for } 30 \mathrm{~min}\end{array}$ & $100 \%(4 / 4)$ & {$[37]$} \\
\hline
\end{tabular}


systematic and thoroughgoing experiments using liposomal magnetite was conducted by Kobayashi and his colleagues. They demonstrated the efficacy of intracellular hyperthermia using magnetite nanoparticles covered with liposomes (using MCLs and AMLs as mentioned above) in animals with several types of tumors, including B16 mouse melanoma ${ }^{47)}$, MM46 mouse mammary carcinoma ${ }^{50)}$, PC3 and LNCaP human prostate cancer cells in athymic mice ${ }^{59)}$, spontaneously occurring primary melanoma in transgenic mice ${ }^{58)}$, T-9 rat glioma ${ }^{30,31)}$, rat prostate cancer PLS10 ${ }^{57)}$, Os515 hamster osteosarcoma ${ }^{53)}$, VX-7 squamous cell carcinomas in rabbit tongue ${ }^{37)}$, and human breast cancer BT474 (HER2-positive) cells in nude mice ${ }^{61)}$. These results are shown in Table III. In these therapeutic experiments, MCLs (net magnetite amount, $3 \mathrm{mg} /$ tumor) were directly injected into solid tumors and the animals were irradiated several times (repeated hyperthermia) for $30 \mathrm{~min}$ with a "solenoid type" alternating magnetic field of 118 $\mathrm{kHz}$. The temperature of the tumor was elevated rapidly by magnetic heating and reached the intended temperature $\left(42-46^{\circ} \mathrm{C}\right)$. In contrast, the rectal temperature or temperatures in tumors lacking the MCLs did not increase. After the alternating magnetic field irradiation, the tumor volume decreased markedly, and complete tumor regression was observed in $96 \%(51 / 53)$ of the animals in these experiments (Table III). These results indicate that MCLs can be an effective tool for hyperthermia, and repeated hyperthermia using magnetite nanoparticles is a promising approach for cancer therapy.

Since magnetite particles larger than $10 \mathrm{~nm}$ in diameter are ferromagnetic and they are moved by the action of a magnet, magnetic force-based targeting for drug and gene delivery has demonstrated the efficacy of this technique ${ }^{75)}$. When tumor tissues are located at peripheral portions of the body, magnetic forces enhance the delivery of magnetite nanoparticles into tumor tissues. This was shown in a rat model by Kobayashi et $a l^{34)}$.

As shown in Fig. 1, MCLs have a ten-fold higher affinity for cells than neutrally charged magnetoliposomes (MLs). Because MCLs may attach to most cells via electrostatic interaction, administration of MCLs has been limited to their direct injection into tumor tissues, which poses problems in treating impalpable lymph node metastases. Kobayashi et al proposed the application of MLs in such cases ${ }^{48)}$. The lymphatic system is an important pathway for metastasis and the lymphatic system is known to selectively clear particulates of up to hundreds of nanometers in diameter. MLs are $94 \mathrm{~nm}$ in size, and MLs injected into the submucosa or intramuscularly were delivered selectively to regional lymph nodes. Subsequently, alternating magnetic field irradiation was found capable of generating induced hyperthermia in lymph node metastases. If a monoclonal antibody against a tumor cell is available, the use of AMLs will be more effective for targeting tumor cells in lymph nodes.

In addition to tumor regression, Kobayashi et al showed that intracellular hyperthermia also induced antitumor immunity ${ }^{32,40,45)}$. Ito et al. reviewed the role of heat shock proteins (HSPs) secreted from heated tumor cells during antigen presentation ${ }^{76,77)}$. These results suggest that an intracellular hyperthermia system can kill, not only heated tumors, but also non-heated tumors, including metastatic cancer cells. Three key elements may be involved in a mechanism based on heat-induced immune response: (i) cytotoxic $\mathrm{T}$ lymphocytes as effector cells, (ii) antigen-presenting cells as an antigen-processing and antigen-presenting agent for HSP-peptide complexes released from necrotic cells, and (iii) HSPs as natural and powerful immunostimulants. In subsequent studies, Kobayashi et al developed novel cancer immunotherapies based on the mechanism of an anticancer immune response via 
HSP expression ; these approaches included injections of cytokines ${ }^{46)}$, recombinant HSP70 ${ }^{52)}$ or dendritic cells ${ }^{55,56)}$, heat inducible TNF- $\alpha$ gene therapy ${ }^{38)}$, and HSP70 gene therapy ${ }^{51)}$. In all of these studies, the combination of intracellular hyperthermia with immunotherapy was more effective than either method used alone.

\section{Clinical trials for intracellular hyperthermia}

Magnetic nanoparticle-mediated hyperthermia has been a largely experimental modality for hyperthermia, because of limitations which must be addressed by the developments of both, drugs (functional and practical magnetic nanoparticles) and apparatus (alternating magnetic field generators).

For clinical applications, the toxic properties of the particles are an important issue to consider. Ito et $a l^{49)}$ investigated the toxicity resulting from the systemic administration of MCLs (90 mg, i.p.) in mice ; none of the 10 MCL-treated mice died during the study. Transient accumulation of magnetite was observed in the liver and spleen, but magnetite nanoparticles were cleared from circulation by hepatic Kupffer cells and/or fixed macrophages in the spleen by the 30th day after administration.

The safety of any apparatus must also be guaranteed, as well as the safety of any magnetite agents, before clinical applications can be pursued. Because alternating magnetic field generators are electric appliances which use high voltages and currents, insulators must be carefully placed where any contact with a patient's body will occur. Temperature monitoring systems are also important for the safe use of intracellular hyperthermia generated by alternating magnetic field generators. Generally, temperature monitoring during alternating magnetic field irradiation is performed by using fiber-optic thermometry probes which should not be affected by magnetic field exposure. In experimental animal models, the probes were positioned at tumor surfaces ${ }^{31)}$, at the margin of tumors ${ }^{23)}$, and/or inserted into the center of the tumors ${ }^{23)}$.

In 2005, Johannsen et $a l^{11)}$ described the first clinical application of magnetite nanoparticle-mediated hyperthermia in locally recurrent prostate cancer, using the sophisticated $\mathrm{MFH}$ 300F apparatus which was mentioned above. In this study, the feasibility of hyperthermia was evaluated using the MFH 300F apparatus and aminosilane-coated magnetite nanoparticles. The particles were prepared by MagForce Nanotechnology Co. (Berlin, Germany) and the method of preparation has not been published. The nanoparticles were injected transperineally into the prostate of a 67 year-old patient under transrectal ultrasound and fluoroscopy guidance. Treatments were performed using an alternating magnetic field of $100 \mathrm{kHz}$. The temperature was measured in the first and last of six weekly hyperthermia sessions with $60 \mathrm{~min}$ durations using fiber-optic thermometry probes positioned in the prostate, urethra, rectum, perineum, scrotum and left ear. In addition, since the magnetite nanoparticles displayed a visible contrast at therapeutic concentrations on a CT scanner, and could be detected down to $0.01 \mathrm{~g} / 1 \mathrm{Fe}$ in the MRI, a non-invasive temperature estimation system was used for the clinical hyperthermia treatment planning system ${ }^{12)}$. Surprisingly, it was reported that the treatment was well tolerated without anesthesia by using a specially designed cooling device. In the first patient treated, the maximum and minimum intraprostatic temperatures were $48.5^{\circ} \mathrm{C}$ and $40.0^{\circ} \mathrm{C}$ during the first treatment, and $42.5^{\circ} \mathrm{C}$ and $39.4^{\circ} \mathrm{C}$ during the sixth treatment. These data mark a significant development in intracellular hyperthermia. 
In October 2007, Saida et al at Shinshu University in collaboration with Kobayashi et al began a clinical application of magnetite nanoparticle-mediated hyperthermia using AMLs conjugated with MAbs against human high molecular weightmelanoma associated antigen (HMW-MAA) in melanoma ${ }^{13)}$. The magnetic field applicator (a ferrite core-inserted solenoid type) was applied with an alternating magnetic field of $110 \mathrm{kHz}$ as shown in Fig. 4. The safety of the applicator, as well as of the AMLs, was investigated before clinical applications. The AMLs were injected into melanoma nodules, and treatments were performed for $30 \mathrm{~min}$, and repeated three times at $24 \mathrm{~h}$ intervals. The temperatures at the surface of the melanoma nodules were monitored with a fiber optic thermometer, and were maintained between 44 and $46^{\circ} \mathrm{C}$. The patients did not suffer from pain derived from the hyperthermia treatments.

In 2007, Jimbow et al at Sapporo Medical University ${ }^{14)}$

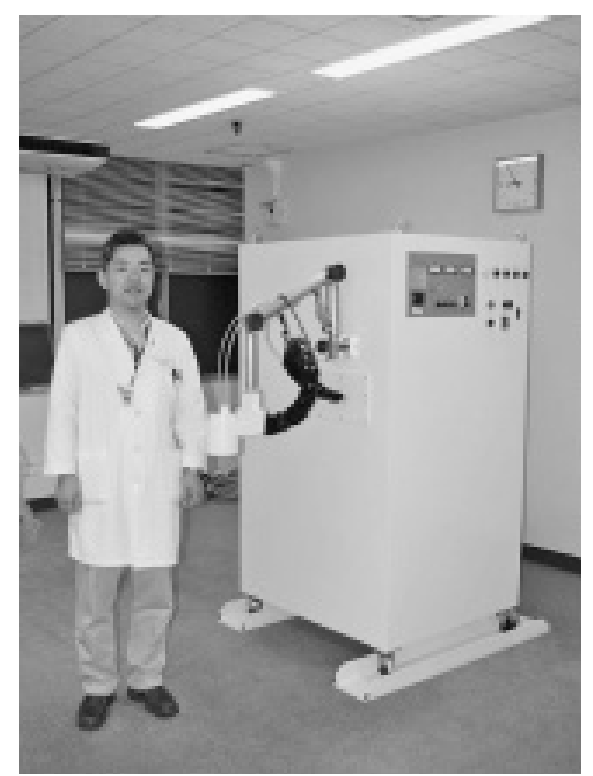

Fig. 4. Magnetic field applicator for clinical applications. also described the clinical application of magnetite nanoparticle-mediated hyperthermia using NPrCAP/M for melanoma, using a ferrite core-inserted solenoid type developed by the Dai-Ichi High Frequency Co. In this study, they evaluated the feasibility of using chemo-thermotherapy with NPrCAP/M and also resultant antitumor immunity. Since they have not yet presented any clinical data in a peer-reviewed journal, their detailed report is now awaited.

\section{Closing comments}

Many continuous efforts have been made to construct a safe and effective intracellular hyperthermia system. Finally, some researchers are opening the door to clinical trials, suggesting that the time has come to use this method. Other groups, including the authors of this review, are now preparing to begin clinical studies. Once the door has opened, many potent combination therapies based on intracellular hyperthermia ${ }^{78)}$ will also be available for clinical trials. The authors hope that intracellular hyperthermia will provide a novel effective therapy for cancer patients.

\section{Acknowledgements}

This work was partially supported by a Grant-in-Aid for Scientific Research (No. 19360378 and No. 20015044) from the Ministry of Education, Science, Sports and Culture of Japan, a Health and Labor Sciences Research Grant-in-Aid for Research on Advanced Medical Technology from the Ministry of Health, Labor and Welfare. 


\section{References}

1) Cavaliere R., Ciocatto E.C., Giovanella B.C., Heidelberger C., Johnson R.O., Margottini M., Mondovi B., Moricca G., Rossi-Fanelli A.: Selective heat sensitivity of cancer cells. Biochemical and clinical studies. Cancer, 20 : 1351-1381, 1967.

2) Dawey W.: Arrhenius relationships from the molecule and cell to the clinic. Int J Hyperthermia, 10 : 457-483, 1994.

3) Harmon B.V., Takano Y.S., Winterford C.M., Gobe G.C.: The role of apoptosis in the response of cells and tumours to mild hyperthermia. Int J Radiat Biol, 59: 489-501, 1991.

4) Fairbairn J.J., Khan M.W., Ward K.J., Loveridge B.W., Fairbairn D.W., O’Neill K.L.: Induction of apoptotic cell DNA fragmentation in human cells after treatment with hyperthermia. Cancer Lett, 89: 183-188, 1995.

5) Hildebrandt B., Hegewisch-Becker S., Kerner T., Nierhaus A., Bakhshandeh-Bath A., Janni W., Zumschlinge R., Sommer H., Riess H., Wust P.: The German Interdisciplinary Working Group on Hyperthermia. : Current status of radiant whole-body hyperthermia at temperatures $>41.5$ degrees $\mathrm{C}$ and practical guidelines for the treatment of adults. The German 'Interdisciplinary Working Group on Hyperthermia'. Int J Hyperthermia, 21 : 169-183, 2005.

6) Fujimoto S., Kobayashi K., Takahashi M., Nemoto K., Yamamoto I., Mutou T., Toyasawa T., Ashida T., Hayashi S., Igarashi N., Ohkubo H. : Clinical pilot studies on pre-operative hyperthermic tumour ablation for advanced breast carcinoma using an $8 \mathrm{MHz}$ radiofrequency heating device. Int J Hyperthermia, 19: 13-22, 2003.

7) Lee C.K., Song C.W., Rhee J.G., Foy J.A., Levitt S.H. : Clinical experience using 8 MHz radiofrequency capacitive hyperthermia in combination with radiotherapy: results of a phase I/II study. Int J Radiat Oncol Biol Phys, 32 : 733-745, 1995.

8) Kakehi M., Ueda K., Mukojima T., Hiraoka M., Seto O., Akanuma A., Nakatsugawa S. : Multi-institutional clinical studies on hyperthermia combined with radiotherapy or chemotherapy in advanced cancer of deep-seated organs. Int J Hyperthermia, $6:$ 719-740, 1990.

9) Moroz P., Jones S.K., Gray B.N. : Magnetically mediated hyperthermia : current status and future directions. Int J Hyperthermia, $18: 267-284,2002$.

10) Ito A., Shinkai M., Honda H., Kobayashi T. : Medical application of functionalized magnetic nanoparticles. J Biosci Bioeng, 100 : 1-11, 2005.

11) Johannsen M., Gneveckow U., Eckelt L., Feussner A., Waldofner N., Scholz R., Deger S., Wust P., Loening S.A., Jordan A. : Clinical hyperthermia of prostate cancer using magnetic nanoparticles : presentation of a new interstitial technique. Int J Hyperthermia, 21: 637-647, 2005.

12) Sreenivasa G., Gellermann J., Rau B., Nadobny J., Schlag P., Deuflhard P., Felix R., Wust P.: Clinical use of the hyperthermia treatment planning system hyperplan to predict effectiveness and toxicity. Int J Rad Oncol Biol Phys, 55 : 407-419, 2003.

13) Takata M., Matsumoto K., Saida T., Kobayashi T. : Heat immunotherapy for advanced melanoma. S3-4, 25th Annual Meeting of Jpn Soc for Thermal Medicine, Nagoya 2008.

14) Jimbow K., Takada T., Sato M., Sato A., Kamiya T., Ono I., Yamashita T., Tamura Y., Sato S., Miyamoto A., Ito A., Honda H., Wakamatsu K., Ito S.: Melanin biology and translational research strategy; melanogenesis and nanomedicine as the basis for melanoma-targeted DDS and chemothermoimmunotherapy. Pigment Cell Melanoma Res, $21: 243-244,2008$.

15) van der Zee J.: Heating the patient: a promising approach? Ann Oncol, 13: 1173-1184, 2002.

16) Gordon R.T., Hines J.R., Gordon D. : Intracellular hyperthermia. A biophysical approach to cancer treatment via intracellular temperature and biophysical alterations. Med Hypothesis, $5:$ 83-102, 1979.

17) Jordan A., Wust P., Fähling H., John W., Hinz A., Felix R. : Inductive heating of ferrimagnetic particles and magnetic fluids : physical evaluation of their potential for hyperthermia. Int J Hyperthermia, 9: 51-68, 1993. 
18) Mitsumori M., Hiraoka M., Shibata T., Okuno Y., Masunaga S., Koishi M., Okajima K., Nagata Y., Nishimura Y., Abe M., Ohura K., Hasegawa M., Nagae H., Ebisawa Y.: Development of intra-arterial hyperthermia using a dextran-magnetite complex. Int J Hyperthermia, 10: 785-793, 1994.

19) Mitsumori M., Hiraoka M., Shibata T., Okuno Y., Nagata Y., Nishimura Y., Abe M., Hasegawa M., Nagae H., Ebisawa Y.: Targeted hyperthermia using dextran magnetite complex : a new treatment modality for liver tumors. Hepatogastroenterol, 43 : 1431-1437, 1996.

20) Mitsumori M., Shibata T., Nagata Y., Hiraoka M., Hasegawa M., Nagae H., Kito K.: Time course change of the heat-generating capability of dextran magnetite complex (DM) in vivo. Jpn J Hyperthermic Oncol, 17: 85-91, 2001.

21) Kawashita M., Sadaoka K., Kokubo T., Saito T., Takano M., Araki N., Hiraoka M. : Enzymatic preparation of hollow magnetite microspheres for hyperthermic treatment of cancer. J Mater Sci : Mater Med, 17 : 605-610, 2006.

22) Tazawa K., Wada S., Yatsuzuka M., Saito T., Tazawa K., Nagano I., Igarashi K., Furuta I., Nagae H. : Development of a portable inductive heating system using dextran magnetite complex (DM) - heating characteristics in vitro and the antitumor effect in VX-2 tumor-bearing rabbits - . Jpn J Hyperthermic Oncol, 19 : 79-87, 2003.

23) Wada S., Tazawa K., Furuta I., Nagae H.: Antitumor effect of new local hyperthermia using dextran magnetite complex in hamster tongue carcinoma. Oral Dis, $9:$ 218-223, 2003.

24) Yamazaki Y., Nagano I., Yagitani S., Maeda T., Igarashi K., Terai K., Nagae H., Tazawa K. : Heating characteristics of dextran magnetite under a strong AC magnetic field created by a portable magnetic generator. 2nd Japan, Australia and New Zealand Joint Seminar, Appl Electromagnetic Phenom Electri Mechan Syst, 24-25, 2002.

25) Shinkai M., Matsui M., Kobayashi T.: Heat properties of magnetoliposomes for local hyperthermia. Jpn J Hyperthermic Oncol, 10 : 168-177, 1994.

26) Shinkai M., Suzuki M., Iijima S., Kobayashi T. : Antibody-conjugated magnetoliposomes for targeting cancer cells and their application in hyperthermia. Biotechnol Appl Biochem, 21 : 125-137, 1994.

27) Suzuki M., Shinkai M., Kamihira M., Hanaichi T., Kobayashi T. : Preparation and characteristics of magnetite-labeled antibody with the use of poly (ethylene glycol) derivatives. Biotechnol Appl Biochem, 21 : 335-346, 1995.

28) Shinkai M., Yanase M., Honda H., Wakabayashi T., Yoshida J., Kobayashi T. : Intracellular hyperthermia for cancer using magnetite cationic liposome - in vitro study - . Jpn J Cancer Res, 87 : 1179-1183, 1996.

29) Suzuki M., Honda H., Kobayashi T., Wakabayashi T., Yoshida J., Takahashi M. : Development of a target-directed magnetic resonance contrast agent using monoclonal antibody-conjugated magnetic particles. Brain Tumor Pathol, 13 : 127-132, 1996.

30) Yanase M., Shinkai M., Honda H., Wakabayashi T., Yoshida J., Kobayashi T. : Intracellular hyperthermia for cancer using magnetite cationic liposomes : Ex vivo study. Jpn J Cancer Res, 88 : 630-632, 1997.

31) Yanase M., Shinkai M., Honda H., Wakabayashi T., Yoshida J., Kobayashi T. : Intracellular hyperthermia for cancer using magnetite cationic liposomes : an in vivo study. Jpn J Cancer Res, 89 : 463-469, 1998.

32) Yanase M., Shinkai M., Honda H., Wakabayashi T., Yoshida J., Kobayashi T. : Antitumor immunity induction by intracellular hyperthermia using magnetite cationic liposomes. Jpn J Cancer Res, 89 : 775-782, 1998.

33) Shinkai M., Yanase M., Suzuki M., Honda H., Wakabayashi T., Yoshida J., Kobayashi T. : Intracelluar hyperthermia for cancer using magnetic cationic liposomes. J Magn Magn Mater, 194 : 176-184, 1999.

34) Suzuki M., Shinkai M., Yanase M., Ito A., Honda H., Kobayashi T. : Enhancement of uptake of magnetoliposome by magnetic force and hyperthermic effect on tumor. Jpn J Hyperthermic Oncol, 15 : 79-87, 1999.

35) Shinkai M., Ueda K., Ohtsu S., Honda H., Kobayashi T. : Effect of functional magnetic particles on radiofrequency capacitive heating. Jpn J Cancer Res, 90 : 699-704, 1999.

36) Le B., Shinkai M., Kitade T., Honda H., Yoshida J., Wakabayashi T., Kobayashi T. : Preparation of tumor-specific magnetoliposomes and their application for hyperthermia. J Chem Eng Jpn, 34 : 66-72, 2001.

37) Matsuno H., Tohnai I., Mitsudo K., Hayashi K., Ito M., Shinkai M., Kobayashi T., Yoshida J., Ueda M. : Interstitial 
hyperthermia using magnetite cationic liposomes inhibit to tumor growth of VX-7 transplanted tumor in rabbit tongue. Jpn J Hyperthermic Oncol, 17 : 141-149, 2001.

38) Ito A., Shinkai M., Honda H., Kobayashi T. : Heat-inducible TNF- $\alpha$ gene therapy combined with hyperthermia using magnetic nanoparticles as a novel tumor-targeted therapy. Cancer Gene Ther, 8: 649-654, 2001.

39) Shinkai M., Le B., Honda H., Yoshikawa K., Shimizu K., Saga S., Wakabayashi T., Yoshida J., Kobayashi T.: Targeting hyperthermia for renal cell carcinoma using human MN antigen-specific magnetoliposomes. Jpn J Cancer Res, 92 : 1138-1145, 2001.

40) Ito A., Shinkai M., Honda H., Wakabayashi T., Yoshida J., Kobayashi T. : Augmentation of MHC class I antigen presentation via heat shock protein expression by hyperthermia. Cancer Immunol Immunother, 50: 515-522, 2001.

41) Shinkai M., Ueda K., Ohtsu S., Honda H., Kohri K., Kobayashi T.: Effect of functional magnetic particles on radiofrequency capacitive heating: an in vivo study. Jpn J Cancer Res, 93 : 103-108, 2002.

42) Shinkai M., Ueda K., Ohtsu S., Honda H., Kohri K., Inoue J., Kobayashi T. : Characteristics of particulate heating mediator in RF capacitive heating. Jpn J Hyperthermic Oncol, 18 : 33-40, 2002.

43) Ohno T., Wakabayashi T., Takemura A., Yoshida J., Ito A., Shinkai M., Honda H., Kobayashi T. : Effective solitary hyperthermia treatment of maglignant glioma using stick type CMC-magnetite. In vivo study. J Neuro-Oncol, 56 : 233-239, 2002.

44) Shinkai M., Ueno K., Honda H., Kobayashi T. : Magnetite needle as heating mediator for intracellular hyperthermia of tumor. Jpn J Hyperthermia Oncol, 18 : 191-198, 2002.

45) Ito A., Shinkai M., Honda H., Yoshikawa K., Saga S., Wakabayashi T., Yoshida J., Kobayashi T. : Heat shock protein 70 expression induces an antitumor immunity during intracellular hyperthermia using magnetite nanoparticles. Cancer Immunol Immunother, 52 : 80-88, 2003.

46) Ito A., Tanaka K., Kondo K., Shinkai M., Honda H., Matsumoto K., Saida T., Kobayashi T.: Tumor regression by combined immunotherapy and hyperthermia using magnetic nanoparticles in an experimental subcutaneous murine melanoma. Cancer Sci, 94 : 308-313, 2003.

47) Suzuki M., Shinkai M., Honda H., Kobayashi T.: Anticancer effect and immune induction by hyperthermia of malignant melanoma using magnetite cationic liposomes. Melanoma Res, 13 : 129-135, 2003.

48) Hamaguchi S., Tohnai I., Ito A., Mitsudo K., Shigetomi T., Ito M., Honda H., Kobayashi T., Ueda M.: Selective hyperthermia using magnetoliposomes to target cervical lymph node metastasis in a rabbit tongue tumor model. Cancer Sci, 94 : 834-839, 2003.

49) Ito A., Nakahara Y., Tanaka K., Kuga Y., Honda H., Kobayashi T.: Time course of biodistribution and heat generation of magnetite cationic liposomes in mouse model. Jpn J Hyperthermic Oncol, 19: 151-159, 2003.

50) Ito A., Tanaka K., Honda H., Abe S., Yamaguchi S., Kobayashi T.: Complete regression of mouse mammary carcinoma with a size greater than $15 \mathrm{~mm}$ by frequent repeated hyperthermia using magnetite nanoparticles. J Biosci Bioeng, 96 : 364-369, 2003.

51) Ito A., Matsuoka F., Honda H., Kobayashi T. : Heat shock protein 70 gene therapy combined with hyperthermia using magnetic nanoparticles. Cancer Gene Ther, 10: 918-925, 2003.

52) Ito A., Matsuoka F., Honda H., Kobayashi T. : Anititumor effects of combined therapy of recombinant heat shock protein 70 and hyperthermia using magnetic nanoparticles in an experimental subcutaneous murine melanoma. Cancer Immunol Immunother, 53 : 26-32, 2004.

53) Matsuoka F., Shinkai M., Honda H., Kubo T., Sugita T., Kobayashi T.: Hyperthermia using magnetite cationic liposomes for hamster osteosarcoma. Bio Mag Res Technol, 2: 3-18, 2004.

54) Ito A., Kuga Y., Honda H., Kikkawa H., Horiuchi A., Watanabe Y., Kobayashi T.: Magnetite nanoparticle-loaded anti-HER2 immunoliposomes for combination of antibody therapy with hyperthermia. Cancer Lett, 212: 167-175, 2004. 
Thermal Med. 24 [4]: 2008

55) Tanaka K., Ito A., Kobayashi T., Kawamura T., Shimada S., Matsumoto K., Honda H. : Intratumoral injection of immature cells enhances antitumor effect of hyperthermia using magnetic nanoparticles. Int J Cancer, 116: 624-633, 2005.

56) Tanaka K., Ito A., Kobayashi T., Kawamura T., Shimada S., Matsumoto K., Saida T., Honda H.: Heat immunotherapy using magnetic nanoparticles and dendritic cells for T-lymphoma. J Biosci Bioeng, 100 : 112-115, 2005.

57) Kawai N., Ito A., Nakahara Y., Futakuchi M., Shirai T., Honda H., Kobayashi T., Kohri K. : Anticancer effect of hyperthermia on prostate cancer mediated by magnetite cationic liposomes and immune-response induction in transplanted syngeneic rats. Prostate, 64: 373-381, 2005.

58) Ito A., Nakahara Y., Fujioka M., Kobayashi T., Takeda T., Nakashima I., Honda H.: Complete regression of hereditary melamona in a mouse model by repeated hyperthermia using magnetite cationic liposomes. Jpn J Hyperthermic Oncol, 21 : 139-149, 2005.

59) Kawai N., Ito A., Nakahara Y., Honda H., Kobayashi T., Futakuchi M., Shirai T., Tozawa K., Kohri K. : Complete regression of experimental prostate cancer in nude mice by repeated hyperthermia using magnetite cationic liposomes and a newly developed solenoid containing a ferrite core. Prostate, 66: 718-727, 2006.

60) Ikehara Y., Niwa T., Le B., Kabata S., Ohashi N., Kobayashi T., Shimizu Y., Kojima N., Nakanishi H.: A carbohydrate recognition-based drug delivery and controlled release system using intraperitoneal macrophages as a cellular vehicle. Cancer Res, 66 : 8740-8748, 2006.

61) Kikumori T., Kobayashi T., Sawaki M., Imai T. : Anti-cancer effect of hyperthermia on breast cancer by magnetite nanoparticle-loaded anti-HER2 immunoliposomes. Breast Cancer Res Treat, DOI 101007/s10549-008-9948-x, 2008.

62) Hasegawa M., Hokkoku S. : Magnetic ion oxide-dextran complex and process for its production. US Patent $4: 101$ : 435, July 18, 1978.

63) Hergt R., Dutz S., Mueller R., Zeisberger M. : Magnetic particle hyperthermia : nanoparticle magnetism and materials developmemt for cancer therapy. J Phys Condens Matter, 18: S2919-S2934, 2006.

64) Thomas P.D., Kishi H., Cao H., Ota M., Yamashita T., Singh S., Jimbow K. : Selective incorporation and specific cytocidal effect as the cellular basis for the antimelanoma action of sulphur containing tyrosine analogs. J Invest Dermatol, 113 : 928-934, 1999.

65) Takahashi H., Tanaka R., Uzuka T., Grinev I. : Stereotactic technique for radio-frequency antenna implantation for brain tumor treatment - Technical note and report of complications. Jpn J Hyperthermic Oncol, 21 : 221-229, 2005.

66) Stauffer R., Cetas T.C., Fletcheretal T.C. : Observation on the use of ferromagnetic implants for inducing hyperthermia, IEEE Trans Biomed Eng, BME-31: 76-90, 1984.

67) Chan D., Kirpotin D.B., Bunn P.A.: Synthesis and evaluation of colloidal magnetic iron oxides for the site-specific radiofrequency-induced hyperthermia of cancer. J Magn Magn Mater, 122 : 374-378, 1993.

68) Panhurst Q.A., Connolly J., Jones S.K., Dobson J. : Application of magnetic nanoparticles in biomedicine. J Phys D : Appl Phys, 36: R167-R181, 2003.

69) Hergt R., Andrae W., d'Ambly C.G., Hilger I., Kaiser W.A., Richter U., Schmidt H.G. : Physical limits of hyperthermia using magnetite fine particles. IEEE Trans Magnetics, 34 : 3745-3754, 1998.

70) Okawa K., Sekine M., Maeda M., Tada M., Abe M. : Heating ability of magnetite nanobeads with various sizes for magnetic hyperthermia at $120 \mathrm{kHz}$, a noninvasive frequency. J Appl Physics, 99: 08H102-08H108, 2006.

71) Atsumi T., Jeyadevan B., Sato Y., Tohji K.: Fundamental studies of hyperthermia using magnetic particles as thermo-seeds 1: Development of magnetic particles suitable for hyperthermia. J Magn Soc Jpn, 30: 555-560, 2006.

72) Gneveckow U., Jordan A., Scholz R., Bruss V., Waldofner N., Ricke J., Feussner A., Hildebrandt B., Rau B., Wust P. : Description and characterization of the novel hyperthermia- and thermoablation-system MFH 300F for clinical magnetic fluid hyperthermia. Med Phys, 31 : 1444-1451, 2004.

73) Jordan A., Scholz R., Maier-Hauff K., van Landeghem F.K., Waldoefner N., Teichgraeber U., Pinkernelle J., Bruhn H., 
Neumann F., Thiesen B., von Deimling A., Felix R. : The effect of thermotherapy using magnetic nanoparticles on rat malignant glioma. J Neurooncol, 78 : 7-14, 2006.

74) Johannsen M., Thiesen B., Jordan A., Taymoorian K., Gneveckow U., Waldofner N., Scholz R., Koch M., Lein M., Jung K., Loening S.A. : Magnetic fluid hyperthermia (MFH) reduces prostate cancer growth in the orthotopic Dunning R3327 rat model. Prostate, 64 : 283-292, 2005.

75) Dobson J.: Magnetic micro- and nano-particle-based targeting for drug and gene delivery, Nanomed, 1: 31-37, 2006.

76) Ito A., Kobayashi T., Honda H. : A mechanism of antitumor immunity induced by hyperthermia. Jpn J Hyperthermic Oncol, $21: 1-19,2005$.

77) Ito A., Honda H., Kobayashi T.: Cancer immunotherapy based on intracellular hyperthermia using magnetite nanoparticles : a novel concept of "heat-controlled necrosis" with heat shock protein expression. Cancer Immunol Immunother, $55:$ 320-328, 2006.

78) Wust P., Hildebrandt B., Sreenivasa G., Rau B., Gellermann J., Riess H., Felix R., Schlag P.M. : Hyperthermia in combined treatment of cancer. Lancet Oncol, 3 : 487-497, 2002. 